\title{
Painted shark vertebrae beads from the Djawumbu-Madjawarrnja complex, western Arnhem Land
}

Duncan Wright, Michelle C. Langley, Sally K. May, Iain G. Johnston \& Lindy Allen

To cite this article: Duncan Wright, Michelle C. Langley, Sally K. May, lain G. Johnston \& Lindy Allen (2016) Painted shark vertebrae beads from the Djawumbu-Madjawarrnja complex, western Arnhem Land, Australian Archaeology, 82:1, 43-54

To link to this article: http://dx.doi.org/10.1080/03122417.2016.1164356

曲 Published online: 09 May 2016.

Submit your article to this journal $ָ$

Џ Article views: 1

Q View related articles $\sqsubset$

View Crossmark data ¿ 


\title{
Painted shark vertebrae beads from the Djawumbu-Madjawarrnja complex, western Arnhem Land
}

\author{
Duncan Wright ${ }^{a}$, Michelle C. Langley ${ }^{b}$, Sally K. May ${ }^{a}$, lain G. Johnston ${ }^{a}$ and Lindy Allen ${ }^{c}$ \\ ${ }^{a}$ School of Archaeology \& Anthropology, Research School of Humanities \& the Arts, College of Arts \& Social Sciences, Australian \\ National University, Canberra, ACT, Australia; ${ }^{b}$ Department of Archaeology \& Natural History, School of Culture, History \& Language, \\ College of Asia and the Pacific, Australian National University, Canberra, ACT, Australia; 'Humanities Department, Collections, \\ Research \& Exhibitions Division, Museum Victoria, Carlton, VIC, Australia
}

\begin{abstract}
In Europe and Africa, fine grained use wear and residue analyses of various organic bead technologies have provided remarkable information about specialist artisans and their affiliate communities. Ethnographic research suggests that personal ornaments represent one of the best ways to explore past human interactions and ethno-linguistic diversity. The study of material culture featured in rock art is now well established in Australia, but few detailed analyses have concentrated on personal ornaments recovered from the archaeological record. Fewer still have assessed the potential of this medium for assessing regional variations, despite rich ethnographic histories which point to the significance of these objects for self-differentiating communities and/or clans. This paper examines a collection of painted shark vertebrae beads recently discovered during archaeological survey in Arnhem Land. Detailed morphometric and use wear analysis is presented for these ornaments, alongside Aboriginal oral traditions, and assessment of similar artefacts held in museum collections across Australia. The potential of this combined approach within the Australian context is discussed, including how these studies add to our understanding of group signifying behaviour.
\end{abstract}

ARTICLE HISTORY

Accepted 4 March 2016

\section{Introduction}

Personal ornaments (including items termed 'beads' and 'pendants') consist of objects worn on the body and which serve to demonstrate affiliations with or distinctions between members of the same or nearby communities (Wiessner 1983, 1984; Wobst 1977). This behaviour is specific to humans (both Modern Humans and Neanderthals: Bouzouggar et al. 2007; Henshilwood et al. 2004; Morin and Laroulandie 2012; Romandini et al. 2014; Taborin 1987; Zilhão et al. 2010), and has provided archaeologists with numerous insights into the cognitive development, cultural variability and cultural interaction of various communities throughout Africa, Western Asia and Europe (e.g. Álvarez-Fernandez and Joris 2008; Kuhn and Stiner 2007; Vanhaeren and d'Errico 2006; White 2007a, 2007b). Studies have demonstrated the value of detailed analysis of bead assemblages to isolate the 'systemic relationships that existed at an ethno-linguistic level between different [(pre)historic] population clusters' (Vanhaeren and d'Errico 2006:1123; see also Taborin 1987).

In Australia, rock art has been used to establish regionalisation and boundedness of past communities (e.g. David and Lourandos 1998; Mulvaney 2012;
Taçon 1993). It has been argued that stylistic 'groups' may have increased during the late Holocene, potentially overlapping with ethno-linguistic regions (e.g. David and Lourandos 1998). Examples of this correlation occur in Northern Australia where rock art style 'boundaries' parallel ethnographically-stated clan groups (David 2002; Taçon 1993). On Cape York, an expansive tradition of engraved geometric figures shifted to a dualistic division of painted motifs, closely correlating with two ethnographicallyknown regions (David 1991; David and Cole 1990; David and Lourandos 1998). This duality was also observed in a number of other regions of Queensland (Lourandos 1997) and Western Arnhem Land (Taçon 1993, 1994). Furthermore, Taçon (1994:119) observed one case where an ethnographically recorded clan boundary was apparent through a '47 metre non-engraved gap' between two sets of distinctive, totemic motifs.

Similarly, regional variation may occur in material culture distributions as exemplified in the Australian context by Western Australian stone point traditions (Hiscock 1994). Alternatively, distinctive sites and site type combinations may occur as was the case for burials in South East Australia, South East 
Queensland and New South Wales (Barker 2004; Hope and Littleton 1995; Pardoe 1988; Pate 1995; Webb 1989). The establishment of new communities may result in increased territoriality, but also formalised intergroup alliances and social gatherings associated with ceremonies, trade and exchange (David and Lourandos 1998:198; Dortch 2002:13; Lourandos 1997; McNiven 1999:162; McNiven and Feldman 2003:171). The lowering of inter- and intra-community restrictions in particular places and on particular occasions may result in site complexes that include multiple features that are otherwise regionally discrete (Wright 2011).

While a number of publications have incorporated Australian portable art objects in an assessment of human cognitive development (e.g. Balme and Morse 2006; Balme et al. 2009; Brumm and Moore 2005; Davidson 2007; Davidson and Noble 1992; Habgood and Franklin 2008; O'Connell and Allen 2007), temporal and regional variation across the Australian continent has received less attention.

Without providing an exhaustive review of Australian Pleistocene and early Holocene beads, the likes of which have been given by several authors previously (Balme 2000; Balme and Morse 2006; McAdams 2008; Morse 1993), we would like to highlight the pervasiveness of hard animal materials for personal ornaments used in this southern continent. In all confirmed cases of Pleistocene and early Holocene personal ornamentation, it has been marine shell (Dentalium sp., Conus sp., Melo sp., Nerita sp., Geloina sp., Anadara sp., Hyriidae sp., scaphopod: as found at Riwi, Mandu Mandu Creek, Carpenter's Gap 1, Cape Range Peninsula, Bundeena, Capertee, Nawamoyn) or terrestrial animal bone or teeth (primarily macropod, but also Dasyurid and Sarcophagus harrisii: as found at Devil's Lair, Kow Swamp, Lake Nitchie, Roonka, Cooma, Wallpolla Island) which have been targeted for use (Balme 2000; Balme and Morse 2006; Dortch 1979, 1980; Feary 1996; Harper 1899; Irish 2007; McCarthy 1964; Morse 1993; O'Connor 1995; Pardoe 1995; Pate et al. 1998; Pretty 1977; Przywolnik 2003; Schrire 1982; Figure 1). As recognised by McAdams (2008:15; and in line with European research by Vanhaeren and d'Errico 2006), there is clear evidence for spatial patterning of beads in Australia, along with 'ethnolinguistic associations with bead distributions'.

Taphonomic factors are expected to have significantly influenced the survival of Pleistocene portable art objects within the Australian setting (Langley et al. 2011). It is intriguing, however, that these objects are also poorly represented in published Holocene archaeologies. The paucity of published articles runs contrary to the rock art, which provides pictographic evidence for the existence of a vast corpus of portable art objects throughout Australia's
Aboriginal past. For example, the figures in the Dynamic Figure rock art in Arnhem Land, Northern Territory are frequently depicted with arm and neck ornaments and headdresses decorated with tassels and feathers (Chaloupka 1984, 1993), while a possible stencil of a tooth necklace, reminiscent of that found on the (Holocene) Lake Nitchie burial, has also been found (Macintosh et al. 1970). Similarly, the prominence (and variety) of personal ornaments during the late Holocene is evident in ethnographic studies (e.g. Akerman and Stanton 1994; Allen and Hamby 2013; Hamby and Young 2001; McAdams 2008; Roth 1904) and museum collections (cf. Hamby 2005; Lakic 1995; May 2009; Peterson et al. 2008; Simak 2007). Significant numbers of neck ornaments were recorded and collected by Donald Thomson from Cape York and Arnhem Land in the 1920s and 1930s (Allen 2008), and by Charles Mountford in Arnhem Land in 1948 (see May 2008, 2009). In addition, Alfred Haddon in the Torres Strait collected thousands of coix seeds, dog teeth, and shell beads which adorn necklaces, armlets, tobacco pipes, skull caps, and a beheading knife (Moore 1984). McAdams' (2008) doctoral thesis has identified the scale and significance of bead assemblages in Australia, and also the extent to which these objects lie buried in consultancy and museum reports.

In keeping with their better known African and European counterparts, these Australian artefacts have provided insights into the communities which produced them. For example, new forms of symbolic expression, which include portable art objects, appear across the continent after the Antarctic Cold Reversal (ACR 14.5-12.5 ka; Langley et al. 2011; Williams et al. 2013). Necklaces, headbands and armbands are frequently found associated with burials during this period, and include the remarkable Roonka burials located on the Murray River in South Australia (Pretty 1977). At this site, 70 inhumations were recorded in layers dating to approximately $4000 \mathrm{BP}$. The burial of a man and child contained a wallaby teeth headdress and armband, a pendant made from a bird skull and a necklace of reptile vertebrae. Ochre was found on the feet of the child along with other items of personal adornment. This form of archaeology consequently provided rare insight into the socio-political and ceremonial underpinnings of late Holocene communities living in this region (Pretty 1977:301; see also Pardoe 1995).

With these facts in mind, we now present an object biography for a small collection of vertebrae beads collected from Mirarr Country, located in the Northern Territory. Through use wear analysis and a review of ethnography and museum collections, we will present an outline of how these few beads can inform us about artisan and community identities. 


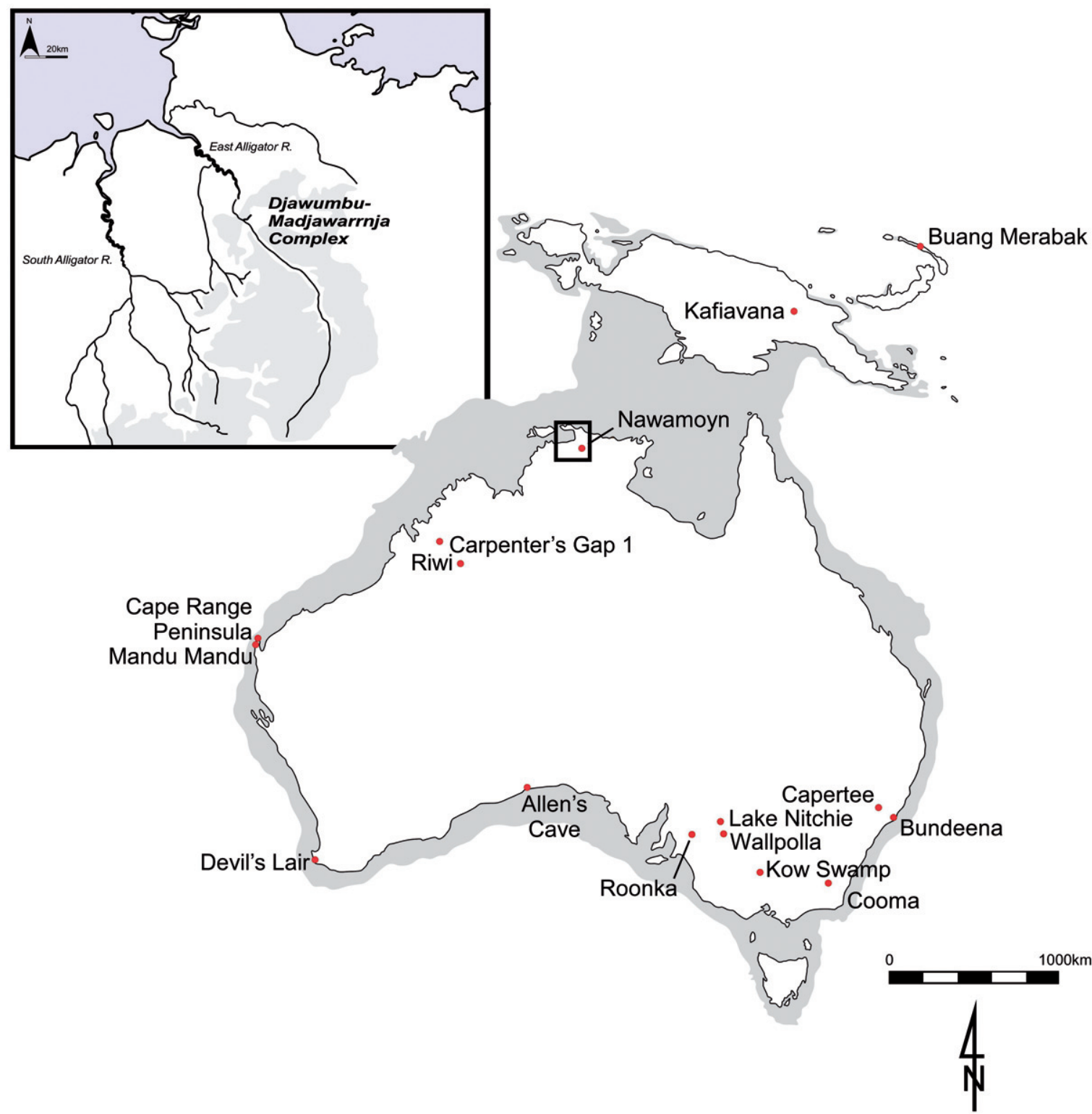

Figure 1. Distribution of beads and pendants identified in Australian Pleistocene sites.

Ultimately, we hope that the data presented here demonstrate the importance of undertaking such focused analyses and wide-reaching regional comparisons of Australian ornamentation and other portable art objects.

\section{Archaeological context}

The discovery of six small painted shark vertebrae beads within the Jabiluka leasehold area, western Arnhem Land, provides the opportunity to reexamine the distribution and role of distinctive cartilaginous ornaments in far north Australia. The site is located near the top of the Djawumbu Massif, an isolated sandstone outlier on the eastern margin of the Magela flood plain. This outlier is approximately $3 \mathrm{~km}$ long, $1 \mathrm{~km}$ wide (at the widest point), and located along the Oenpelli-Jabiru road (to the west). The top of Djawumbu varies between a sparsely vegetated, boulder-strewn plain in the south/centre to a maze of eroded passageways, chambers and rockshelters in the north and west. The latter area contains a large quantity of cultural sites, including rock art, stone arrangements and grinding hollows.

In 2013/14, surveys of Djawumbu were completed by the authors (SKM, DW) as part of a Mirarr community funded project (Mirarr Gunwardibim; see Wright et al. 2014 for details). These surveys confirmed results from previous studies (Cundy 1982; Kamminga and Allen 1973; Morley and Lovett 1980), identifying a high density of sites (including rock art, stone arrangements, lithic scatters and burials). One site (R1 0018 16/07/2013), a rockshelter located on a substantial ledge near the top of Djawumbu (the exact location is restricted at the request of the Mirarr traditional owners), consisted of one of four rock art panels along this ledge (sizes ranged from 1 to $5 \mathrm{~m}$ in length, with the larger sites containing over 100 motifs). The shelter in question measured $17 \mathrm{~m}$ in length, with nine grinding hollows and large chunks of roof fall located on the shelter floor (Figure 2). 


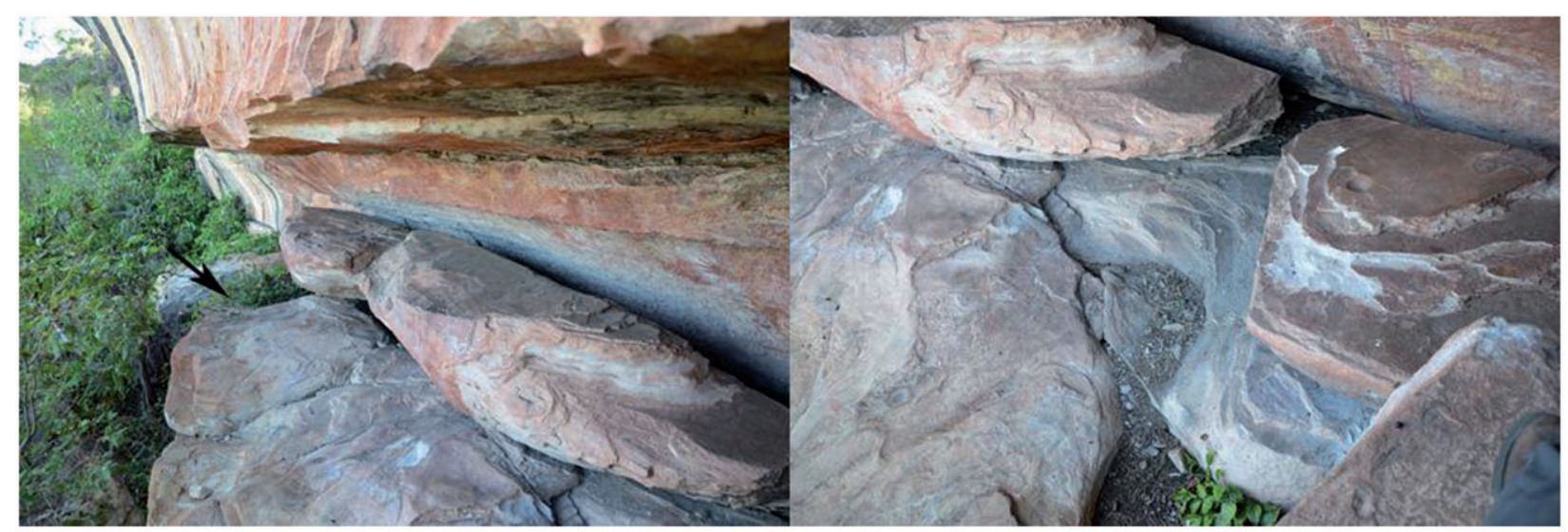

Figure 2. The site where the beads were located with arrow indicating one of the sediment traps (shown centrally in second photograph) (photo: I. Johnston).

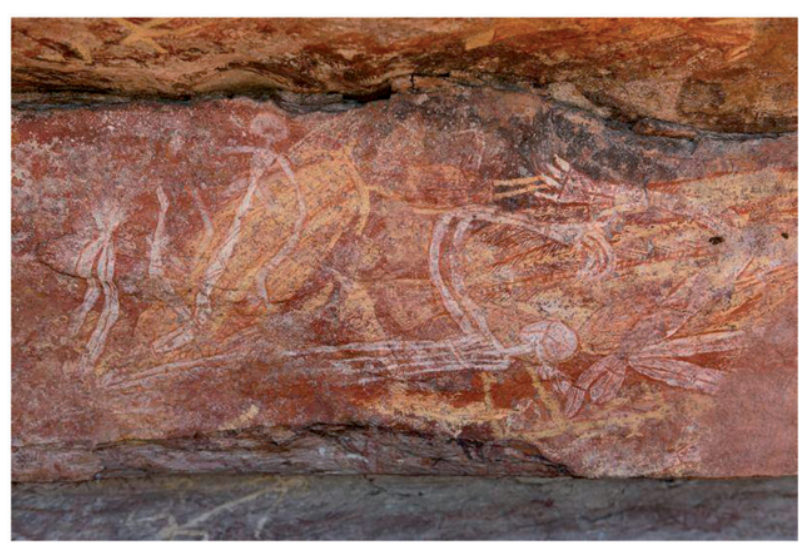

Figure 3. One of the painted panels from the site showing depictions of white human-like figures, fish, and a variety of other superimposed subject matter (photo: D. Wright, 2013).

The shelter housed over 500 rock art motifs located on wall and boulder panels (see, for example, Figure 3). The vast majority of motifs are characteristic of late Holocene freshwater period art (Chaloupka 1993). Subject matter includes turtles, fish, reptiles, macropods, flying foxes and human figures with body adornments (including feathered headdresses but with no clear depictions of beaded body adornments) and assorted material culture, such as spearthrowers. Nearly all of the art is produced using pigment, but there are examples of beeswax art in both geometric form and as human-like figures.

When the site was visited, in June 2014, small pools of water survived in a wet season water channel $50 \mathrm{~m}$ south of the main shelter. It was observed that wet season run off had scoured recesses of the shelter, and transported soil across the shelter. Three sediment traps (formed against rock fall basins) were noted in the northern end of this shelter. The largest was $2.66 \mathrm{~m}$ wide at the shelter wall, tapering to 1.03 $\mathrm{m}$ wide at the drip line before spilling down slope.

In 2013, three beads and a small bone point were collected from eroded spill $1.5 \mathrm{~m}$ in front of the main deposit. This eroded sediment contained large quantities of cultural materials. A partially exposed human long bone (probable femur) was observed in a shallow sediment trap in the centre of the shelter. A small fragment of turtle shell (unknown species) was observed in the same area, alongside a small, undiagnostic terrestrial vertebrate long bone, one freshwater mussel (Velesunio angasi) valve, and several small fish bones (undiagnostic). Most probably originating from a macropod, the recovered bone point features a triangular cross-section and measures only $27.3 \mathrm{~mm}$ in total length, $3.2 \mathrm{~mm}$ at its maximum width, and $3 \mathrm{~mm}$ at maximum thickness. Like the vertebrae beads described below, this piece exhibits a thick layer of red ochre (Figure 4). Microscopic analysis revealed post-depositional damage to the distal tip, along with crushing and rounding which is consistent with use as an awl or similar action. Given its size, painted decoration, and association with the beads it is possible that this artefact was also used for ornamentation, such as a nose pin, its size being consistent with these items and which could conceivably accrue this same type of wear. The mesial section of the artefact exhibits a small indentation and traces of a black residue (Figure 4: C), which would also be consistent with use as a pin.

In 2014, two additional complete beads and one broken example were found cemented within sediment at the back of the rockshelter. These beads were collected with seven unpainted and unaltered fish vertebrae. A single human tooth, a molar, with roots attached was recorded in this context. No subsurface investigation was undertaken, with additional cultural materials likely to remain buried at this site.

\section{The Djawumbu vertebrae beads}

Microscopic and morphological analysis undertaken by one of us (MCL) was completed for all six of the recovered beads. Identification and recording of manufacturing marks and use wear follows the methods developed by d'Errico (1993), d'Errico and Villa (1997), and White $(1995,2007 a, 2007 b)$. Based on a review of the ANU Archaeology and Natural History 


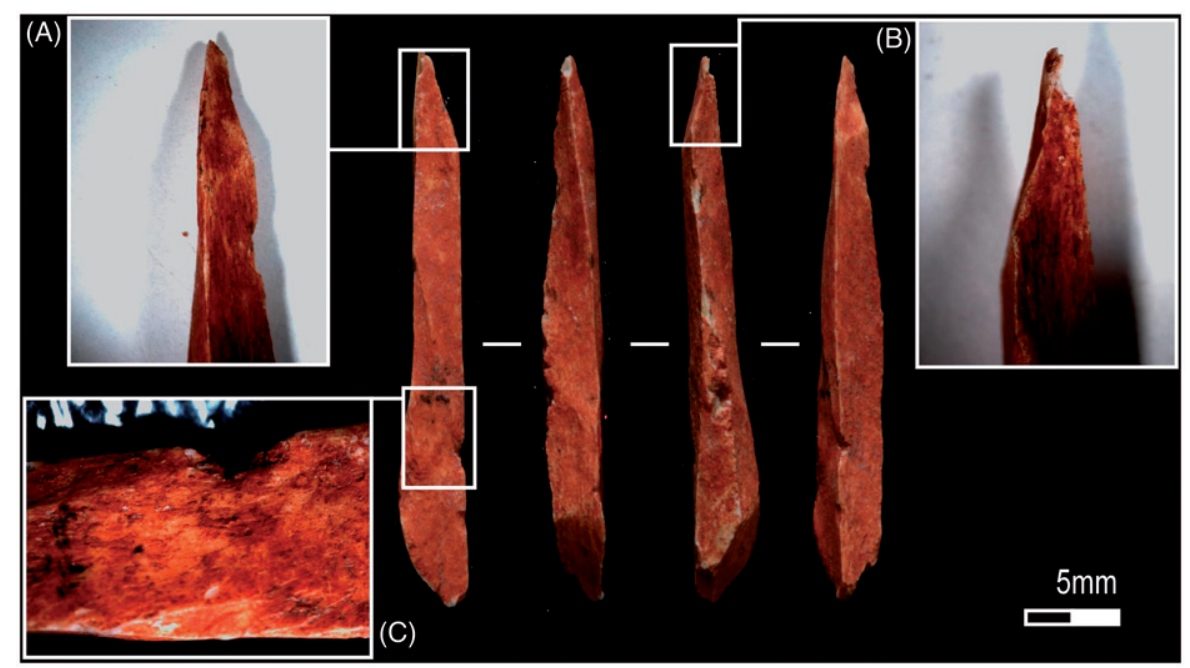

Figure 4. Small bone point found alongside the six bone beads. This point appears to be covered in the same red colourant as the beads. (A) Superior surface $(8 \times)$; (B) Inferior surface $(12.5 \times)$; and (C) notch and black reside $(16 \times)$.

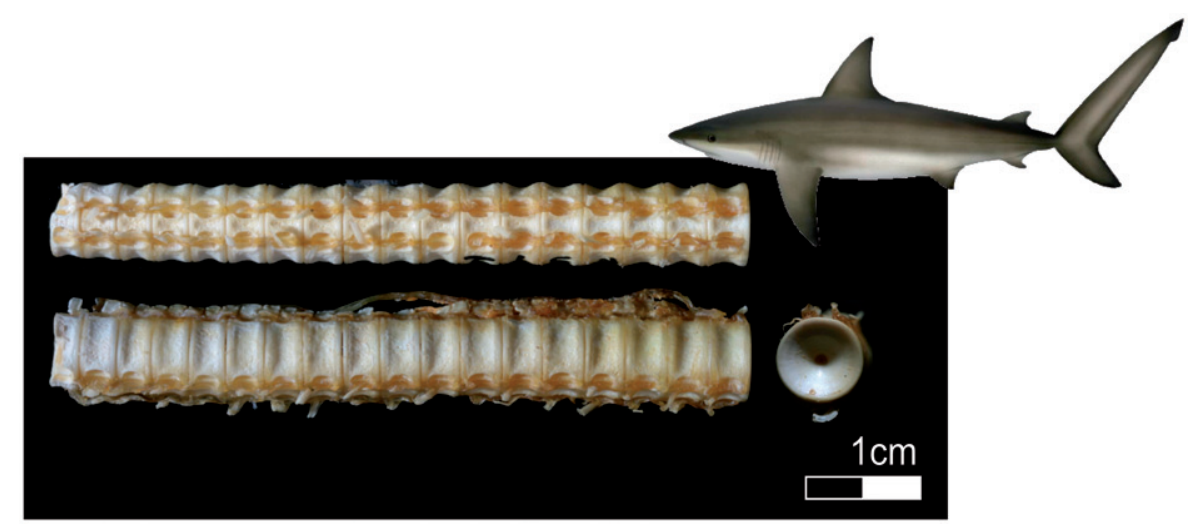

Figure 5. Reference collection example of vertebrae from a Bronze Whaler (Carcharhinus brachyurus). Bronze whaler image http://www.dpi.nsw.gov.au/fisheries/recreational/saltwater/sw-species/bronze-whaler

Table 1. Metrics of the Djawumbu vertebrae beads.

\begin{tabular}{|c|c|c|c|c|c|}
\hline \multicolumn{4}{|c|}{ Whole bead } & \multicolumn{2}{|c|}{ Perforation } \\
\hline Bead \# & $\begin{array}{c}\text { Max. } \\
\text { Width }\end{array}$ & $\begin{array}{c}\text { Max. } \\
\text { Height }\end{array}$ & $\begin{array}{c}\text { Max. } \\
\text { Thickness }\end{array}$ & $\begin{array}{l}\text { Max. } \\
\text { Width }\end{array}$ & $\begin{array}{c}\text { Max } \\
\text { Height } \\
\end{array}$ \\
\hline Bead 1 & 5.2 & 5.3 & 2.4 & 1.7 & 2.0 \\
\hline Bead 2 & 4.3 & 3.7 & 2.3 & 1.5 & 1.6 \\
\hline Bead 3 & 5.0 & 4.4 & 2.4 & 1.2 & 1.6 \\
\hline Bead 4 & 5.0 & 5.2 & 2.5 & 1.3 & 1.4 \\
\hline Bead 5 & 5.0 & 4.8 & 2.4 & 1.7 & 2.1 \\
\hline Bead 6 & na & na & na & na & na \\
\hline
\end{tabular}

Bead numbers correlate with Figure 6.

osteological reference collection, all six beads were found to be consistent with vertebrae belonging to the Carcharhinidae family (Figure 5). This family is commonly known as 'whaler sharks' and includes numerous species, such as bull sharks, spinner sharks, dusky, blacktip and bronze whalers. The beads measure within one to $2 \mathrm{~mm}$ of each other (average: $4.49 \mathrm{~mm}$ maximum height, $4.72 \mathrm{~mm}$ maximum width, $2.43 \mathrm{~mm}$ maximum depth) suggesting that, either they all came from the same animal, or from multiple animals of similar size (Table 1).

Four of the beads are largely intact and complete (Beads 1, 2, 4, 5 in Figure 6), one was collected in three pieces (Bead 6 in Figure 6), and the last is missing a significant portion of one side (Bead 3 in Figure 6). While the artefacts are extremely fragile and there is evidence for low-level fragmentation of small sections of the surface, intact ochre slip across all artefact surfaces suggests little sustained exposure to the elements. Microscopic analysis with a Zeiss 2000-C stereo microscope fitted with a AxioCam MRc5 camera, along with a Dino-Lite AM413ZTAS digital microscope found that the centre of each vertebrae has been worked from both the superior and inferior surfaces as evidenced by the inward curvature of the perforation edges (Figure 7: C). While it is likely that drilling was the technique used, the heavy coating of ochre makes it impossible to identify the curved striations which would confirm this hypothesis. Furthermore, if a wooden drill was used, no such striations would be evident. The holes average $1.5 \mathrm{~mm}$ in width and comparison of the perforations with the reference examples of Carcharhinidae vertebrae clearly demonstrates the significant differences between the natural perforation found in this type of shark vertebrae and the artefacts presented herein (compare reference example to bead perforations in Figure 7). 
Localised use wear consistent with suspension is evident on each of the beads, though it is particularly clear on Beads 1 and 5, where a notch (sometimes known as 'key-holing') is worn into a section of the perforation wall (Figure 7: D). Other evidence for human alteration is found in the creation of a c. $1 \mathrm{~mm}$ deep groove around the circumference of two of the beads (Beads 2 and 3; Figure 8: B and C). In each of these two cases, the groove has almost

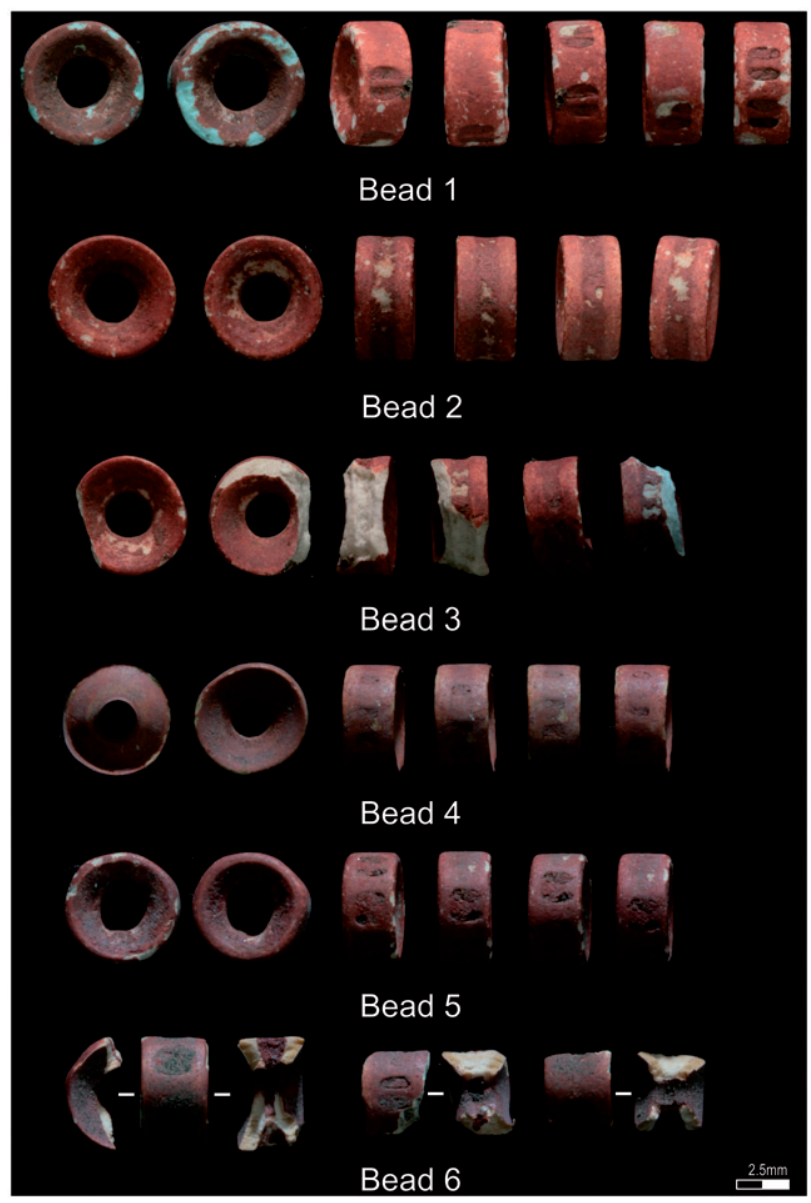

Figure 6. Views of the six Djawumbu shark vertebrae beads recovered. completely removed the paired notches which are diagnostic of shark vertebrae, though close examination finds remnants of these anatomical features allowing us to confirm that they are of the same origin as the remaining four beads. The smooth surfaces of the grooves suggests abrasion as the technique utilised in their manufacture, although again, the heavy coating of ochre inhibits the identification of clear diagnostic marks. The remaining four beads show no evidence for similar alteration of the vertebra edge, here instead the notches are choked with red ochre (Figure 8: A, D and E).

Interestingly, while three of the beads (Beads 1, 2, and 5) exhibit rounding to the proximal edges (Figure 9), the other three (Beads 3, 4 and 6) display edges which are sharper in form and consequently closer to their original (natural) morphology (Figure 8: C). Since intensity along with type of use dictates the severity and type of wear to accumulate on an ornament, the sub-groups identified in the Djawumbu bead assemblage suggests a number of different interpretations. First, the beads may not have been manufactured at the same time, and thus, half were in use longer than the three less worn examples. This interpretation will be discussed further below. Another explanation might be that the more heavily worn beads were utilised differently (used to decorate a different object which of itself was used in a different motion or more intensively) than the other three, resulting in the different levels of wear observed. Given that the beads were found in one locality and display the same ochre coating (see below), we might argue that they all originally belonged to the same item, and thus, the distribution of the two beads with proximal grooves across these two sub-groups (one with more extensive wear and one with less extensive wear) suggests that as many

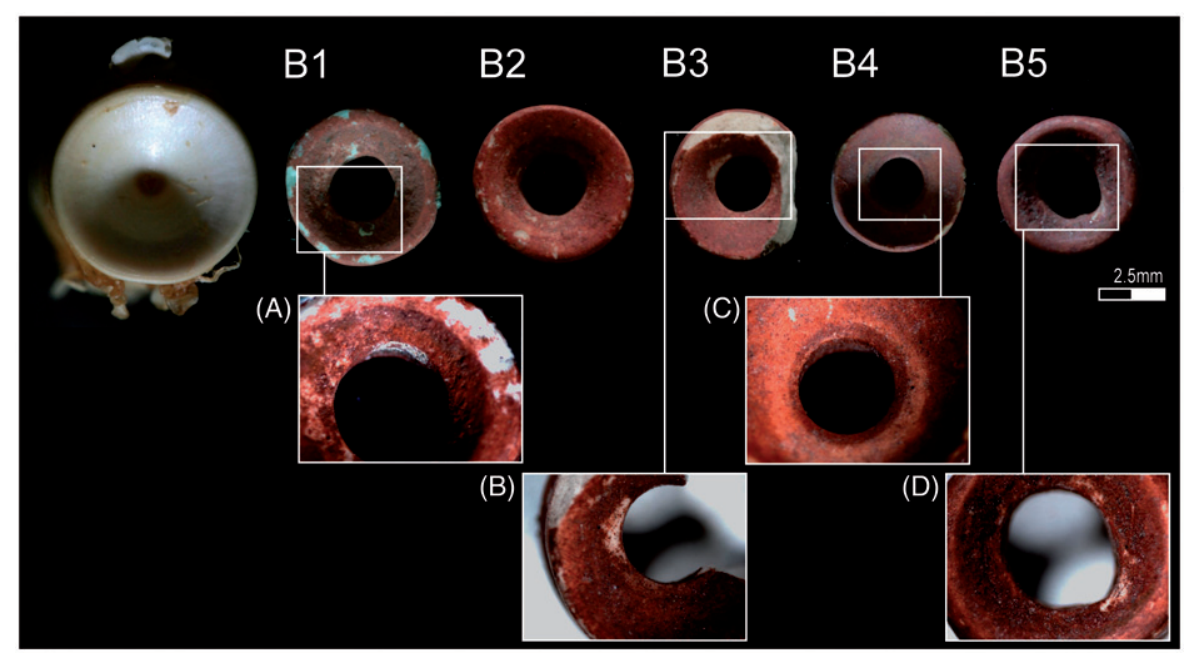

Figure 7. Examples of use wear and colourants identified on dorsal and ventral sides of the Djawumbu beads: (A) White residue inside perforation (20x); (B) Wearing away of red residue on side of perforation $(20 \times)$; (C) Bevelled edges around perforation $(20 \times)$; (D) Example of significant rounding to edges and perforation wear from stringing $(20 \times)$. 
as four manufacturing events may even be represented by this find.

The defining feature of the Djawumbu beads is the heavy and even coating of red colourant. Indeed the coating of all beads is so substantial, that clear traces of manufacturing and use wear are difficult to identify clearly (as mentioned above). This red residue is compacted into the notches located on the sides of each bead (see examples in Figure 8: A, D and $\mathrm{E}$ ), and is lightest on the dorsal and ventral surfaces, although here too thick accumulations are observed (Figure 7: A). Bead 1, Bead 2, Bead 4 and Bead 5 also exhibits traces of a white substance, located primarily around and inside the perforation (Figure 7: A). This residue is also consistent with a colourant, and its sporadic appearance and location suggests that its presence is not intentional (as the even coating of red colourant appears to be), but was rather the by-product of use (such as being transferred from skin or string onto bead).

To summarise, the Djawumbu beads appear to have been bifacially drilled to create perforations large enough to be strung sequentially or attached to an item, before being coated with a red paint mixture and utilised as an item of adornment. A white colourant appears to have been incidentally transferred to the perforations of several of these beads, suggesting that the string, person/s, or item against which these beads came into contact during their use life was coated with a white colourant. Three of these beads exhibit more extensive wear than the others, suggesting that they experienced more intensive use before deposition. That all but one of these beads were recovered intact suggests that it was not bead breakage which resulted in their discard, but rather another process, which may include stringing failure, unintentional loss of an item or intentional discard (which may or may not have been ritual in nature).

\section{Discussion}

Detailed analysis of the Djawumbu beads demonstrates staged manufacture of shark vertebrae beads

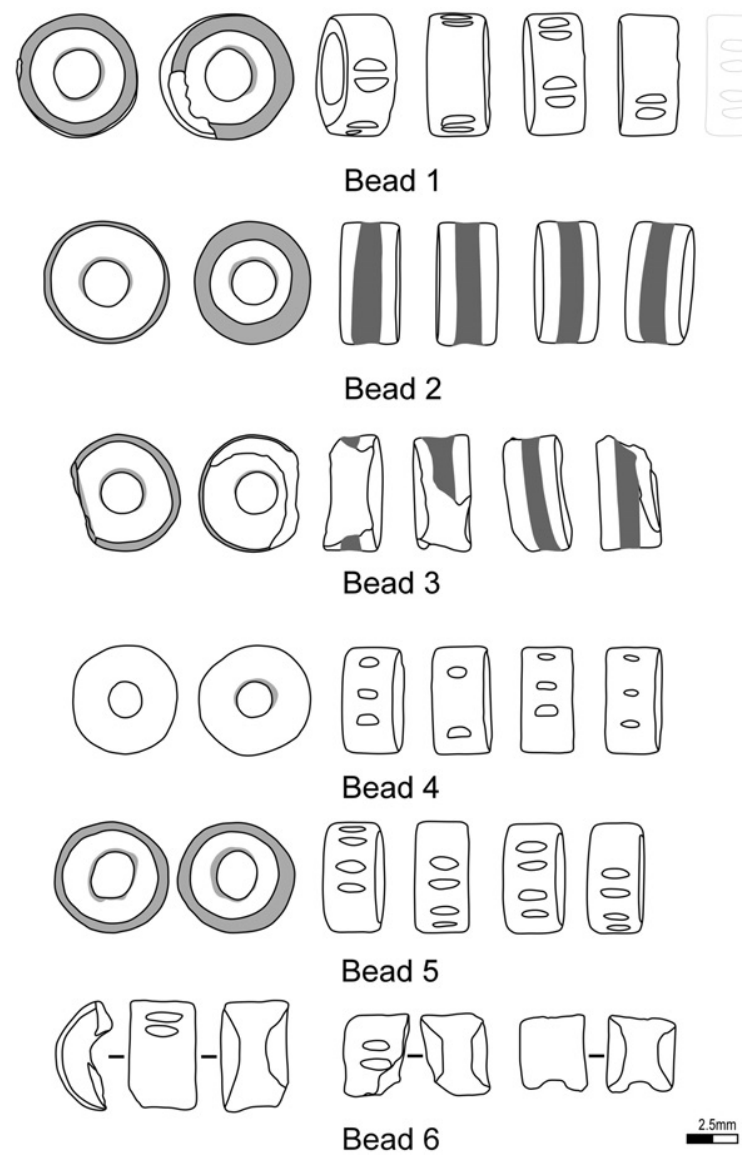

Figure 9. Location of use wear (light grey shading) and more intensive working of Beads 2 and 3 (dark grey shading).

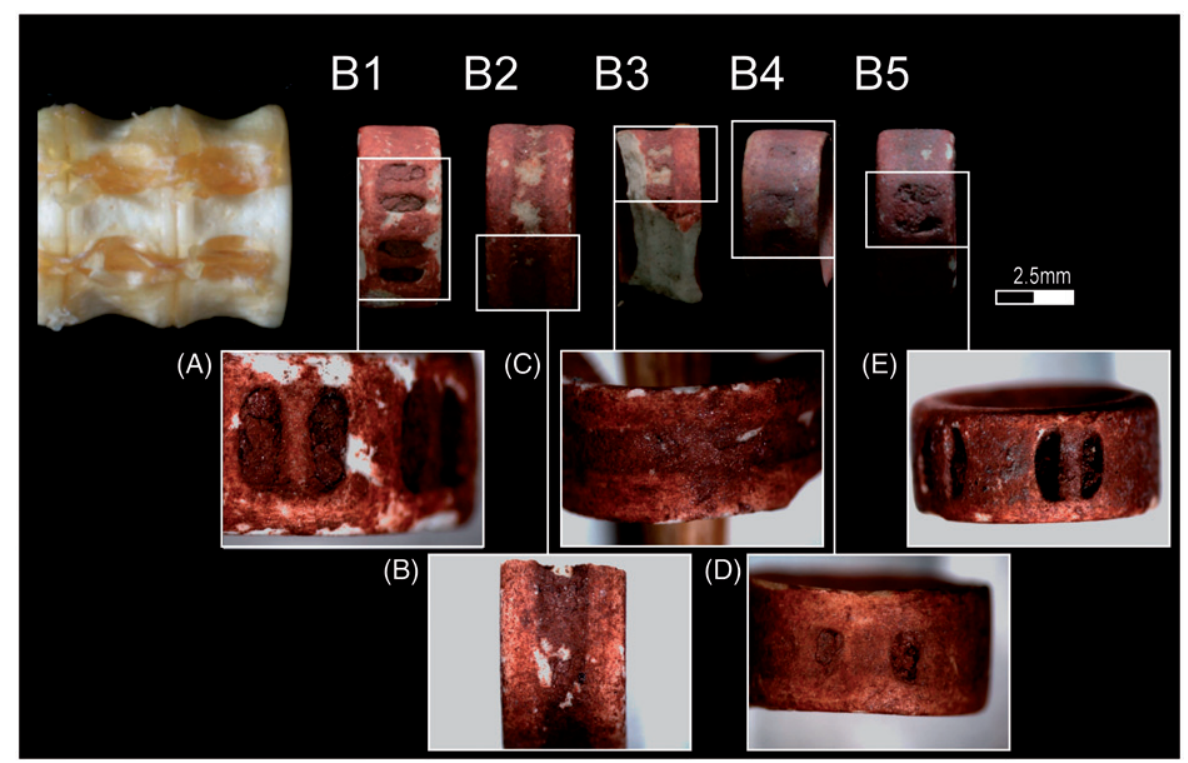

Figure 8. Examples of use wear and colourants identified on sides of the Djawumbu beads: (A, D and E) Colourant buildup in notches (Mag. A: $16 \times$ D: $16 \times$ E: $12.5 \times$ ); B and (C) Groove around side (Mag. B: $16 \times$ C: $20 \times$ ). 

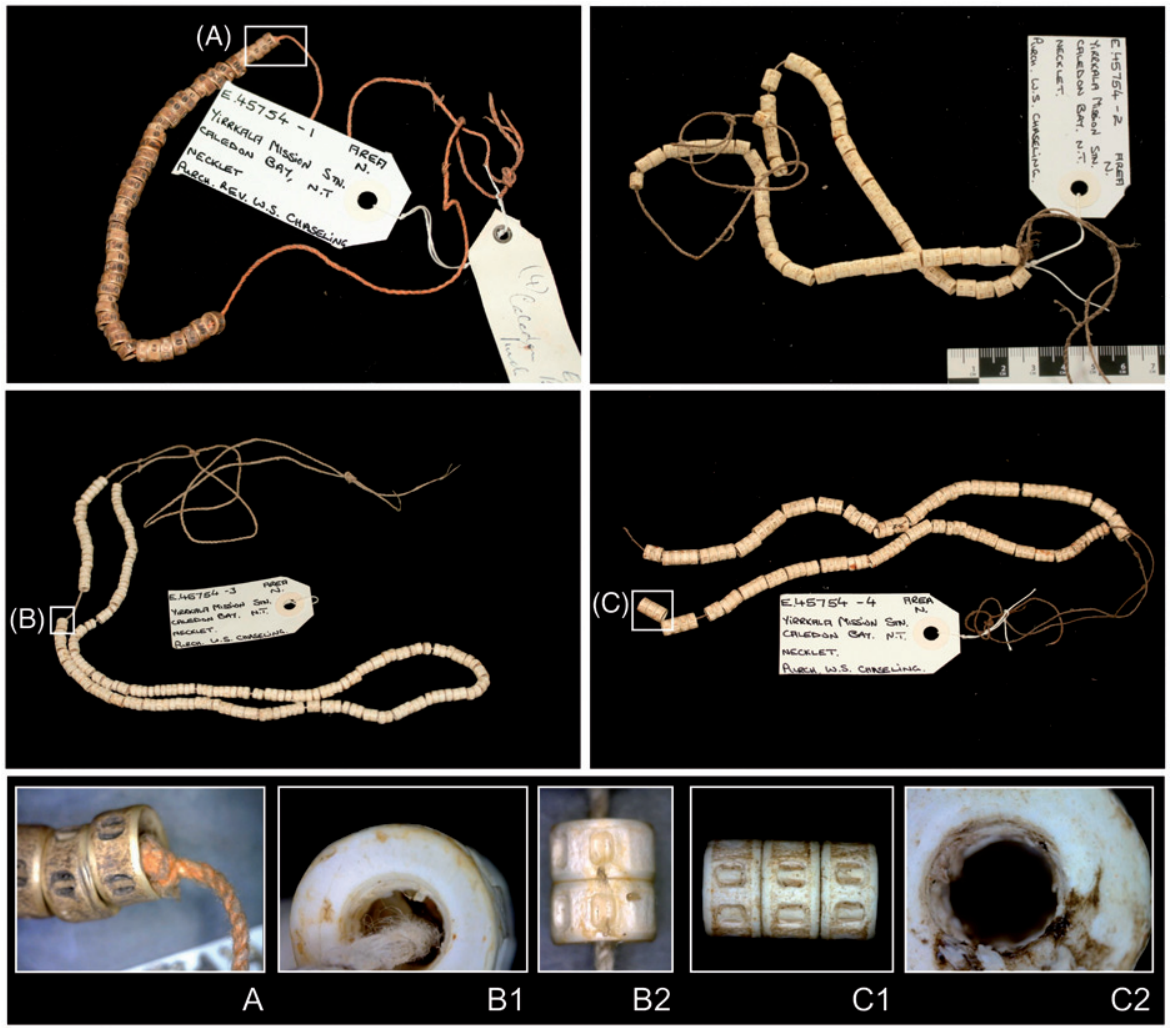

Figure 10. Shark vertebrae bead necklaces from Caledon Bay, Northern Territory, The Australian Museum (Sydney). (A) Red colourant staining on string; (B1 and C2) striations around perforation wall; (B2 and C1) Multiple vertebrae still in anatomical connection (Photos: M.C. Langley with permission from The Australian Museum, Sydney).

(involving grinding, piercing and coating with red ochre), while comparison of the Djawumbu beads to four ethnographic strands of shark vertebrae beads collected from Caledon Bay, in the Northern Territory, sheds light on the manufacture and possible use of these artefacts. Importantly, these four examples are not unique. The collections in the Australian Museum (Sydney) include some 46 to $100+$ vertebrae strung consecutively to form necklaces (Figure 10); and an examination of the Donald Thomson Collection by one of us (LA) suggests that shark and fish vertebrae necklaces were frequently threaded onto a single strand of vegetable fibre string.

As the Caledon Bay beads in the Australian Museum are not painted, it was possible to clearly observe striations around the interior of the perforation (Figure 10: B1 and C2). These marks indicate that the centre of the vertebrae was drilled from both sides with the use of a stone point in order for the hole to be large enough for string to be passed through. Rounding similar to that seen on the edges of the Djawumbu beads was also apparent on these ethnographic artefacts (Figure 10: A), where their consecutive arrangement explains the process behind the accumulation of this form of wear. Of additional interest, one of the Caledon Bay examples was strung with string coloured with a red substance consistent with ochre (Figure 10: A).

The presence of vertebrae on these strands from multiple Whaler sharks suggests either systematic and focused hunting of these animals or the gathering of vertebrae from infrequent catches and over an extensive period of time. Additionally, three of the Caledon Bay necklaces feature groups of two to six vertebrae, which are still in anatomical connection (see examples in Figure 10: B2 and C1), suggesting, first, that groups of these beads were taken from the same animal, and second, that the beads were not altered for use individually. Instead, several beads were drilled while still attached to one another. In all, these four ethnographic examples match very well with the archaeologically recovered Djawumbu beads in terms of bead size, working traces and use wear.

While we are not able to provide precise temporal information, the striking similarity of Djawumbu beads to those found in 19th century ethnographic collections and the dominance of late Holocene rock art in the shelter suggests these date to the very recent past. The paucity of sediment in this shelter means that the beads and bone point are likely to have always been on (or near) the surface of the shelter floor. Survival of these delicate artefacts (complete with their ochre slip) for more than 200 years is considered unlikely.

The discovery of the Djawumbu beads enables the reassessment of regional differentiation between lateHolocene communities in Australia. Today, these beads function as social indicators in eastern Arnhem Land where they are intimately associated 
Table 2. Distribution of vertebrae bone personal ornaments observed in museum collections (Adapted from McAdams 2008:487).

\begin{tabular}{lccr}
\hline Location & Fish/Shark & Snake & Total \\
\hline Archer Kendall Holroyd Rivers, QLD & 1 & 1 & 2 \\
Arnhem Land unprovenanced, NT & 15 & 0 & 15 \\
Caledon Bay, NT & 4 & 0 & 4 \\
Cape York East, QLD & 1 & 0 & 1 \\
King Leopold Ranges, NT & 0 & 1 & 1 \\
Mapoon. QLD & 1 & 0 & 1 \\
Milingimbi Island, NT & 8 & 0 & 8 \\
Trial Bay, NT & 1 & 0 & 1 \\
Total & 31 & 2 & 33 \\
\hline
\end{tabular}

Snake vertebrae perforated ornaments appear to share elements of manufacture/decoration with shark and therefore have been included in this table.

with the Galpu and Djapu clans (and the Dhuwa moiety), which have strong connections to the Shark Dreaming (Hamby and Young 2001). It was the responsibility of clan members to hunt sharks and make these ornaments. Rose Marmininy, a senior Galpu woman from Elcho Island, combines shark vertebrae with feathered string (feathers taken from the parrot Trichoglossus rubritorquis). She explained the special importance of shark for DjambarrpuynguGuyula and other Djambarrpuyngu groups: 'we sing this one, this one is ours' (Hamby and Young 2001:16). According to Donald Thomson, these necklaces were given the same generic name used to describe young sharks, which in Yolngu (eastern Arnhem Land) is burrugu, while Clement (1903) was informed that shark vertebrae beads enabled identification of medicine men on the Western Australian coast.

It is plausible that vertebrae necklaces were used as grave goods or as part of funeral and mourning rituals. The Arnhem Land ornaments were found in a shelter containing human skeletal remains. This association was also found to be the case at Roonka in the Lower Murray, with a necklace of snake vertebrae found with the 4000 year old skeleton of a boy (Pretty 1977). Further in situ discoveries are required to test this hypothesis further.

Examination of the Donald Thomson Collection from northern Australia, of which almost a quarter consists of body ornaments, revealed that less than ten per cent of the more than 150 neck ornaments included fish or macropod bone vertebrae. The provenance of these artefacts is northern Australia, the majority (85\%) being collected in Arnhem Land and adjacent islands (Table 2). Snake vertebrae ornaments appear to fit this pattern with two artefacts collected from eastern Cape York and Leopold Ranges in the Kimberley, north Western Australia. It has also been observed that the majority of shark vertebrae beads were recovered from coastal areas, suggesting availability of fish as a prominent consideration (McAdams 2008:487; McCarthy 1940:246).

McAdams (2008:344) noted variation within the repertoire of vertebrae beads. Many artefacts were associated with other beads or ornaments and the majority (33\%) were decorated with colourants (McAdams 2008:344). These findings include the snake vertebrae bead from the King Leopold Ranges, which was attached to a cowry shell, with a pattern formed by arranging light and dark ('possibly stained') vertebrae. The 'two fish/shark series (Arnhem Land unprovenanced and Milingimbi) had feathers attached', with the latter painted with red ochre (McAdams 2008:344). A shark vertebrae necklace collected by W.E. Roth from the Batavia River in east Cape York also appears to be painted with red ochre. McAdams (2008:344) observed that the most highly decorated objects were collected from Arnhem Land, an area which also included the highest variety of materials used in portable art manufacture. In summary, archaeology and ethnography suggests unique social signifying behaviour in far north Australia, specifically Arnhem Land.

\section{Conclusion}

A substantive study of archaeological/ethnographic collections of portable art objects in Australia represents an important next step for Australian archaeology. On this continent we have a great opportunity to link archaeologically recovered items with vast ethnographic collections, rock art images and oral histories (e.g. McAdams 2008). We ask researchers to, where possible, retrieve items of personal adornment from their archives and articulate them to the wider archaeological discourse on this enigmatic class of material culture. In addition, studies such as Wesley and Litster (2015), show us that beads may feature in Australian archaeological sites, and as such, methodologies (e.g. sub-sampling using $1 \mathrm{~mm}$ mesh sieves) must be developed accordingly.

We also suggest that one way to pursue this line of research would be to investigate the viability of a study like that undertaken by Vanhaeren and d'Errico (2006) for Aurignacian personal ornamentation. The combination of ethnographic/ethno-linguistic and archaeological studies are expected to be powerful in the Australian context where significant connections exist between present and past human communities. This combined approach is likely to provide evidence for regionally and temporally discrete innovations by dynamic human communities. Such an approach may also provide information about socio-political developments connected with the emergence of ethno-linguistic (Indigenous) Nations. Based on this paper and previous research into rock art regionalisation (e.g. David 1991, 2002; Taçon 1993, 1994), it is probable that complexities (including totemic identities and socio-ceremonial pathways) behind art expression may become apparent. Establishing regional patterns in rock and 
portable art will allow us to ascertain the extent to which the regional patterns outlined above reflect sampling issues associated with archaeological/ethnographic collection and research.

Importantly, and in keeping with the Western tradition of research, these data may provide invaluable insights into social signifying behaviour in Australia, demographics, cultural interaction, and the impact of past environmental changes on those who inhabited this vast country over the past 50,000 or more years. In other words, it is time to establish personal ornamentation, and portable art in the wider sense, as a subject worthy of study in the Australian archaeological literature.

\section{Acknowledgements}

We would like to thank the Mirarr people and the Gundjeihmi Aboriginal Corporation for their ongoing collaboration and support for Mirarr Gunwarddebim (the Mirarr Rock Art Project). Many people have contributed to the Mirarr Gunwarddebim project in various ways and we thank you for your support. Thanks are especially due to all of the people who have assisted with the rock art surveys since 2011 including (but not limited to) John Hayward, Ines Domingo Sanz, Melissa Marshall, Paul S.C. Taçon, Janet and Phil Davill, Norrae Johnston, Joakim Goldhahn, Matthew Abbott, and Pat Carrick. We are grateful to ERA for permission to access the Jabiluka leasehold area and to the Northern Land Council, AAPA for permits and access to site information and the Natural Cultural Programs Unit (Kakadu National Park). Finally, thanks to Mirani Litster for advice and assistance on northern Australian bead traditions, Stuart Hawkins on the identification of the shark family to which the vertebrae belonged, and Stan Florek for assistance with the ethnographic collections held at The Australian Museum (Sydney).

\section{Disclosure statement}

The authors report no conflicts of interest. The authors alone are responsible for the content and writing of this article.

\section{References}

Akerman, K. and J. Stanton 1994 Riji and Jakoli: Kimberley Pearlshell in Aboriginal Australia. Parap: NT Museum of Arts and Sciences Monograph Series 4. NT Government Printing Office.

Allen, L. 2008 Tons and tons of valuable material: the Donald Thomson collection. In N. Peterson, L. Allen and L. Hamby (eds), The Makers and Making of Indigenous Australian Museum Collections, pp.387-418. Melbourne: Melbourne University Publishing.

Allen, L. and L. Hamby 2013 Aboriginal Australia. In J. Condra (ed), Encyclopedia of National Dress: Traditional Clothing Around the World, Volume1, pp.44-51. Santa Barbara, CA. ABC-CLIO.

Álvarez-Fernandez, E. and O. Joris 2008 Personal ornaments in the early Upper Palaeolithic of Western
Eurasia: an evaluation of the record. Eurasian Prehistory 5:31-44.

Balme, J. 2000 Excavations revealing 40,000 years of occupation at Mimbi Caves, south central Kimberley, Western Australia. Australian Archaeology 51:1-5.

Balme, J., I. Davidson, J. McDonald, N. Stern and P. Veth 2009 Symbolic behaviour and the peopling of the southern arc route to Australia. Quaternary International 202(1-2):59-68.

Balme, J. and K. Morse 2006 Shell beads and social behaviour in Pleistocene Australia. Antiquity 80(310):799-811.

Barker, B. 2004 The Sea People: Late Holocene maritime specialisation in the Whitsunday Islands, Central Queensland, Terra Australia (Vol. 20). Canberra: Pandanus Books.

Bouzouggar, A., N. Barton, M. Vanhaeren, F. d'Errico, S. Collcutt, T. Higham, E. Hodge, S. Parfitt, E. Rhodes, J.L. Schwenninger, C. Stringer, E. Turner, S. Ward, A. Moutmir, and A. Stambouli 2007 82,000-Year-old shell beads from North Africa and implications for the origins of modern human behaviour. Proceedings of the National Academy of Sciences of the United States of America 104(24):9964-9969.

Brumm, A. and M.W. Moore 2005 Symbolic revolutions and the Australian archaeological record. Cambridge Archaeological Journal 15:157-175.

Chaloupka, G. 1984 Rock Art of the Arnhem Land Plateau: Paintings of the Dynamic Figures Style. Unpublished report for the Northern Territory Museum of Arts and Sciences.

Chaloupka, G. 1993 Journey in Time: the World's Longest Continuing Art Tradition: the 50,000-Year Story of the Australian Aboriginal Rock Art of Arnhem Land. Sydney: Reed New Holland.

Clement, E. 1903 Ethnographical notes on the WesternAustralian Aborigines with a descriptive catalogue of a collection of ethnographical objects from western Australia by J.D.E. Shmeltz. Internationales Archiv für Ethnographie 16:1-29.

Cundy, B.J. 1982 Survey of the Archaeological Sites in the Fenced Area of the Jabiluka Mining Project. Unpublished report for Pancontinental Mining Limited, Darwin.

David, B. 1991 Fern Cave, rock-art and social formations: rock-art regionalisation and demographic changes in south-eastern Cape York Peninsula. Archaeology in Oceania 26:41-57.

David, B. 2002 Landscapes, Rock-art and the Dreaming: An Archaeology of Preunderstanding. London: Leicester University Press.

David, B. and N. Cole 1990 Rock-art and inter-regional interaction in northeastern Australian prehistory. Antiquity 64(245):788-806.

David, B. and H. Lourandos 1998 Rock-art and socio-demography in Northeastern Australian prehistory. World Archaeology 30(2):193-219.

Davidson, I. 2007 Tasmanian Aborigines and the origins of language. In J. Mulvaney and H. Tyndale-Biscoe (eds), Rediscovering Recherche Bay, pp.69-85. Canberra: Academy of the Social Sciences in Australia.

Davidson, I. and W. Noble 1992 Why the first colonisation of the Australian region is the earliest evidence of modern human behaviour. Archaeology in Oceania 27(3):113-119.

d'Errico, F. 1993 La vie sociale de l'art mobilier Paléolithique. Manipulation, transport, suspension des 
objets on os, bois de cervidés, ivoire. Oxford Journal of Archaeology 12(2):145-174.

d'Errico, F. and P. Villa 1997 Holes and grooves: the contribution of microscopy and taphonomy to the problem of art origins. Journal of Human Evolution 33:1-31.

Dortch, C.E. 1979 Devil's Lair, an example of prolonged cave use in southwestern Australia. World Archaeology 10:258-279.

Dortch, C.E. 1980 A possible pendant of marl from Devil's Lair, Western Australia. Records of the Western Australian Museum 7:329-367.

Dortch, C.E. 2002 Modelling past Aboriginal hunter-gatherer socio-economic and territorial organization in Western Australia's lower south-west. Archaeology in Oceania 37(1):1-21.

Feary, S. 1996 An Aboriginal burial with grave goods near Cooma, New South Wales. Australian Archaeology 43:40-4.

Habgood, P. and N. Franklin 2008 The revolution that didn't arrive: a review of Pleistocene Sahul. Journal of Human Evolution 55:187-222.

Hamby, L. (ed). 2005 Twined Together: Kunmadj Njalehnjaleken. Gunbalanya: Injalak Arts and Crafts.

Hamby, L. and D. Young 2001. Art on a String: Aboriginal Threaded Objects from the Central Desert and Arnhem Land. Canberra: Object, Australian Centre for Craft \& Design, \& Centre for Cross-Cultural Studies, ANU.

Harper, W.R. 1899 Results of an exploration of Aboriginal rock-shelters at Port Hacking. Proceedings of the Linnean Society of New South Wales 24:322-332.

Henshilwood, C., F. d'Errico, M. Vanhaeren, K. van Niekerk, and Z. Jacobs 2004 Middle stone age shell beads from South Africa. Science 304:404.

Hiscock, P. 1994 The end of points. In M. Sullivan, S. Brockwell and A. Webb (eds), Archaeology in the North: Proceedings of the 1993 Australian Archaeological Association Conference, pp.72-83. Darwin: North Australian Research Unit, Australian National University.

Hope, J. and J. Littleton 1995 Finding out about Aboriginal Burials. Murray Darling Basin Aboriginal Heritage Handbooks. Sydney: Mungo Publications.

Irish, P. 2007. Bundeena Bling? Possible aboriginal shell adornments from southern Sydney. Australian Archaeology 64:46-49.

Kamminga, J. and H. Allen 1973 Report of the Archaeological Survey (Alligator Rivers Environmental Fact-Finding Study). Canberra: Australian Government Publishing Service.

Kuhn, S.L. and M.C. Stiner 2007. Body ornamentation as information technology: towards an understanding of the significance of early beads. In K. Boyle, O. BarYosef, C. Stringer and P. Mellars (eds), Rethinking the Human Revolution, pp. 45-54. Cambridge: McDonald Institute for Archaeological Research.

Lakic, M. 1995 Dress and ornamentation. In L. Allen, M. Lakic, G. Sculthorpe, and R. Wrench (eds), Women's Work: Aboriginal Women's Artefacts in the Museum of Victoria, pp.19-30. Melbourne: Museum Victoria.

Langley, M.C., C. Clarkson and S. Ulm 2011 From small holes to grand narratives: the impact of taphonomy and sample size on the modernity debate in Australia and New Guinea. Journal of Human Evolution 61:197-208.

Lourandos, H. 1997 Continent of Hunter-Gatherers. Cambridge: Cambridge University Press.

May, S.K. 2008 The art of collecting: Charles Pearcy Mountford. In N. Peterson, L. Allen, and L. Hamby (eds),
The Makers and Making of Indigenous Australian Museum Collections, pp.446-471. Melbourne: Melbourne University Publishing.

May, S.K. 2009 Collecting Cultures: Myth, Politics, and Collaboration in the 1948 Arnhem Land Expedition. California: Altamira.

Macintosh, N.W.G., K.N. Smith, and A.B. Bailey 1970 Lake Nitchie Skeleton - Unique Aboriginal Burial. Archaeology \& Physical Anthropology in Oceania 5(2):85-101.

McAdams, L.E 2008 Beads across Australia: An Ethnographic and Archaeological View of the Patterning of Aboriginal Ornaments. Unpublished $\mathrm{PhD}$ (or Masters) thesis, School of Humanities, University of New England, Armidale.

McCarthy, F.D. 1940 Trade in Aboriginal Australia and trade relationships with Torres Straits, New Guinea and Malaya. Oceania 9(4):405-438.

McCarthy, F.D. 1964 The archaeology of the Capertee Valley, New South Wales. Records of the Australian Museum 26(6):197-246.

McNiven, I.J. 1999 Fissioning and regionalisation: the social dimensions of changes in Aboriginal use of the Great Sandy Region, southeast Queensland. In J. Hall and I.J. McNiven (eds), Australian Coastal Archaeology, pp.157-168. Research Papers in Archaeology and Natural History 31. Canberra: ANH Publications, Research School of Pacific and Asian Studies, Australian National University.

McNiven, I.J. and Feldman, R. 2003 Ritually orchestrated seascapes: hunting magic and dugong bone mounds in Torres Strait, NE Australia. Cambridge Archaeological Journal 13(2):169-194.

Moore, D. 1984 The Torres Strait Collections of AC Haddon. London: British Museum Press.

Morin, E. and V. Laroulandie 2012 Presumed symbolic use of diurnal raptors by Neanderthals. PLoS One 7 (3), $1-5$.

Morley, A.W. and D.W. Lovett 1980 Aboriginal Site Survey of the Jabiluka Project Area. Unpublished report for Pancontinental Mining Limited, Environment Division, Jabiluka Division, Darwin.

Morse, K. 1993 Shell beads from Mandu Mandu Creek Rock Shelter, Cape Range Peninsula, Western Australia, dated before 30,000 bp. Antiquity 67:877-883.

Mulvaney, J. 2012 Human cognition: the Australian evidence. Antiquity 86:915-921.

O'Connell, J. and J. Allen 2007 Pre-LGM Sahul (Pleistocene Australia - New Guinea) and the archaeology of early modern humans. In P. Mellars, K. Boyle, O. Bar-Yosef and C. Stringer (eds), Rethinking the Human Revolution, pp.395-410. Cambridge: McDonald Institute for Archaeological Research.

O'Connor, S. 1995 Carpenter's Gap Rockshelter 1: 40,000 years of Aboriginal occupation in the Napier Ranges, Kimberley, W.A. Australian Archaeology 40:58-60.

Pardoe, C. 1988 The cemetery as symbol. The distribution of prehistoric Aboriginal burial grounds in southeastern Australia. Archaeology in Oceania 23(1):1-17.

Pardoe, C. 1995 Riverine, biological and cultural evolution in southeastern Australia. Antiquity 69:696-713.

Pate, D. 1995 Stable carbon isotope assessment of huntergatherer mobility in prehistoric South Australia. Journal of Archaeological Science 22:81-87.

Pate, F.D., G.L. Pretty, R. Hunter, C. Tuniz and E.M. Lawson 1998 New radiocarbon dates for the Roonka 
Flat Aboriginal burial ground, South Australia. Australian Archaeology 46:36-37.

Peterson, N., L. Allen, and L. Hamby 2008 The Makers and Making of Indigenous Australian Museum Collections. Melbourne: Melbourne University Press.

Pretty, G. 1977 The cultural chronology of Roonka Flat: a preliminary consideration. In R.V.S. Wright (ed), Stone Tools as Cultural Markers, pp.288-331. Canberra: Australian Institute of Aboriginal Studies.

Przywolnik, K. 2003 Shell artefacts from Northern Cape Range Peninsula, northwest Western Australia. Australian Archaeology 56:12-21.

Romandini, M., M. Peresani, V. Laroulandie, L. Metz, A. Pastoors, M. Vaquero and L. Slimak 2014 Convergent evidence of eagle talons used by Late Neanderthals in Europe: A further assessment on symbolism. PLoS One 9(7):e101278.

Roth, W.E. 1904 Domestic Implements, Arts and Manufactures. North Queensland Ethnography, Bulletin 7. Brisbane: Government Printer.

Schrire, C. 1982 The Alligator Rivers: Prehistory and Ecology in Western Arnhem Land. Canberra: Australian National University.

Simak, E. 2007 Australian Aboriginal necklaces. The Bead Society of Great Britain Newsletter 89(Autumn):4-7.

Taborin, Y. 1987 Les Coquillages dans la Parure Paléolithique en France. Thése du Doctorat d'Etat. Université de Paris, Paris.

Taçon, P. 1993 Regionalism in the recent rock art of western Arnhem Land, Northern Territory. Archaeology in Oceania 28(3):112-120.

Taçon, P. 1994 Socialising landscapes: the long term implications of signs, symbols and marks on the land. Archaeology in Oceania 29:117-129.

Vanhaeren, M. and F. d'Errico 2006 Aurignacian ethnolinguistic geography of Europe revealed by personal ornaments. Journal of Archaeological Science 33(8):1105-1128.

Webb, S.G. 1989 The Willandra Lakes Hominids. Canberra: Research School of Pacific Studies, The Australian National University.

Wesley, D. and M. Litster 2015 Small, individually nondescript and easily overlooked": contact beads from northwest Arnhem Land in an Indigenous-MacassanEuropean hybrid economy. Australian Archaeology 80:1-16.

White, R. 1995 Ivory personal ornaments of Aurignacian age: Technological, social and symbolic perspecives, pp.29-62. In J. Hahn, M. Menu, Y. Taborin, P. Walter and F. Widemann (eds), Le Travail et l'Usage de l'Ivoire au Paleolithique Superieur: Acts de la Table Ronde, Ravello, 29-31 Mai, 1992. Rome: Istituto Poligrafico e Zecca dello Stato.

White, R. 2007a Technological and social dimensions of "Aurignacian-Age" body ornaments across Europe. In H. Knecht, A. Pike-Tay, and R. White (eds), Before Lascaux: the Complex Record of the Early Upper Paleolithic, pp.277-299. London: CRC.

White, R. 2007b Systems of personal ornamentation in the Early Upper Palaeolithic: methodological challenges and new observations. In P. Mellars, K. Boyle, O. Bar-Yosef and C. Stringer (eds), Rethinking the Human Revolution, pp.287-302. Cambridge: McDonald Institute Monographs.

Wiessner, P. 1983 Style and social information in Kalahari San projectile points. American Antiquity 48:253-276.

Wiessner, P. 1984 Reconsidering the behavioral basis for style: A case study among the Kalahari San. Journal of Anthropological Archaeology 3(3):190-234.

Williams, A.N., S. Ulm, A.R Cook, M.C. Langley and M. Collard 2013 Human refugia in Australia during the Last Glacial Maximum and Terminal Pleistocene: a Geospatial analysis of the $25-12 \mathrm{ka}$ Australian Archaeological Record. Journal of Archaeological Science 40:4612-4625.

Wobst, M.H. 1977 Stylistic behavior and information exchange. In C.E. Cleland (ed), For the Director: Research Essays in Honor of James B. Griffin, pp.317-342. Ann Arbor: Museum of Anthropology, University of Michigan.

Wright, D. 2011 The archaeology of community on Mabuyag (Mabuiag) in the Western Torres Strait, Northeastern Australia. Australian Archaeology 73:49-57.

Wright, D., S.K. May, P.S.C Taçon, and B. Stephenson 2014 A scientific study of a new cupule site in Jabiluka, Western Arnhem Land. Rock Art Research 31(1):92-100. Zilhão, J., D.E. Angelucci, E. Badal-García, F. d'Errico, F. Daniel, L. Dayet, K. Douka, T.F.G. Higham, M.J. Martínez-Sánchez, R. Montes-Bernárdez, S. MurciaMascarós, C. Pérez-Sirvent, C. Roldán-García, M. Vanhaeren, V. Villaverde, R. Wood, and J. Zapata 2010 Symbolic use of marine shells and mineral pigments by Iberian Neandertals. Proceedings of the National Academy of Science 107(3):1023-1028. 